\title{
The Comparison of Endorser Credibility and Corporate Credibility toward Consumer's Purchase Intension of Airlines Ticket
}

\author{
Indah Sari Febrina, Bertina Sjabadhyni ${ }^{1,2}$ \\ ${ }^{1,2}$ Department of Psychology, University of Indonesia. Indonesia \\ E-mail: bert.pioui@yahoo.com
}

\begin{abstract}
This study aims to find out the comparison of celebrity credibility and corporate credibility toward consumer's purchase intention of airlines ticket. The design of this study $2 \times 2$ between subjects factorial design (high vs low endorser credibility and high vs low corporate credibility). Participants were 563 people from Millenial generation aged 21-34 years old. The results indicate that endorsement from celebrity with high credibility generated significantly greater purchase intention compared to endorsement from lowcredibility celebrity. Compared to company with low credibility, company with higher credibility also generated stronger purchase intention compared. There was no interaction effect between the credibility of endorser and corporate credibility on purchase intention. The implication of this study can be useful for marketer to give more attention about celebrity and corporate credibility in making an advertisement.
\end{abstract}

Keywords: airlines advertisement; celebrity endorsement; consumer's purchase intention; endorser credibility; online experiment

\section{Introduction}

The power of the seller and demand of the consumer have been increasing, so the long-term relationship to the consumer is an important thing to sell a product (Mirabi, Akbariyeh, \& Tahmasebifard, 2015). Nowadays, mass media changes the way consumer thinks through emotion, need, desire, and demand. The researchers and advertisers spend millions of dollars conducting consumer research in order to identify factors that influence consumer's purchase intention. One of the factor that influnces is advertisement. According to Mirabi et al. (2015), advertisement is series of promotion that mixes product, price, placem and promotion in advertising proccess. Fatima and Lodhi (2015) stated that in this competitive world, consumer is being exposed thousands of advertisment. Consumers' perception of advertisement determines the perceived quality of the product. Zipporah and Mberia (2015) stated that with the intention of marketing and creating awareness of the product, advertisement is very important thing to facilitate product and service marketing program to target audience.

Advertisement that used traditional media has been an important source for advertisers to give information about their company and product. However, the introduction of the internet and the increasing development of technology ini recent years have been changing the whole views of consumer. It encourages advertisers to have adaptation to the advertisement according to consumer's demands. Hence, internet advertisement has been incredible increasing. Nowadays, there are many companies that focus on competing to make their product more attractive by adopting internet advertisement (Samat et al., 2016). Raju and Kumar (2013) stated that by using internet advertisement, the advertisers can consider mass media and comunication channels that enable easier and faster access to consumer. The advantage of the worldwide internet access is the availability of effective communication between business and consumer. The availability of the promotional 
message, indeed, has been developing rapidly (Tai \& Chang, 2005). According to Gangeshwer (2013), the development of internet advertisement has the potential to decrease product cost and delivery service.

In today's advertisement, having celebrity to endorse a product in order to attract consumers is common. McCormick (2016) stated that celebrity has unique position in advertisement because of their career and the attention that they get from media. Celebrity has ability to make people notice about what they promote. According to Zipporah and Mberia (2014), celebrity endorsement is the use of proof or support from a preferred or trusted source to a product. Consequently, company must choose the appropriate endorser or spokesperson to get consumer's attention. Endorser, as the important source to delivery message in advertisement, has to have credibility, generally conceptualized as endorser's attractiveness, trustworthiness, and expertise (Ohanian, 1990).

Besides endorser, another source credibility that can influence consumer is company reputation. According to Park et al. (2014), consumer's expectaction of company service can provide comparison standard to consumer's judgement about company performance. Some researchers had identified company reputation as important factor of overall company evaluation. Goldsmith et al. (2000) proposed corporate credibility as one of important aspects of company reputation. Corporate credibility described how consumer evaluated company's honesty and expertise. Positive perception about the company can increase the value of the product or service that the company offers. Corporate credibility has two dimensions: company trustworthiness and company expertise (Newell \& Goldsmith, 2001). Company trustworthiness is the extent to which a company is reliable, whereas company expertise is the extent to which a company has competence to convey the product in advertisement.

In endorser credibility, attractiveness, trustworthiness, and expertise of the celebrity can form consumers' attitude that encourage purchase intention. Previous studies have showed that purchase intention can be influenced by using celebrity as endorser (Samat et al., 2016). According to Newell and Goldsmith (2001), perception about company has important role to the development of consumer attitude to the advertisement, perception to the product, and also purchase intention. Low credibility can also cause a problem in generating consumer demand, earn brand preference, and display effective message in advertisement that influnce purchase intention.

Lafferty and Goldsmith (1999) conducted a 2 (high/low endorser credibility) x 2 (high/low corporate credibility) experiment involving one hundred women undergraduate marketing srudents. The product that was used in that study was athletic shoes, while the endorser was Florence Griffith-Joyner, the Olympic Gold medalist, as high credibility endorser and Roseann Barr, an actress, as the low credibility endroser. The study showed that endorser credibility didn't influence purchase intention.

Based on that previous study, the current study will do further research with different endorser and product. The Product that will be used is airlines. Endorser that will be used in airlines advertisement is celebrity because airlines advertisement rarely use celebrity as endorser. Besides that, this study wants to investigate about corporate credibility, since the role and effect of company reputation in airlines industry have not been fully researched (Park et al., 2004). Additionally, the previous study was done in United States, so this study replicated it in the Indonesian context. Since the celebrity and product that were used in this study were different, the researcher would test whether result would differ. Purchase intention was chosen to be dependent variable in this study besides of other advertisement effectiveness variables because according to Kim et al. (2015), celebrity endorsement will substantially influence purchase intention.

This study focuses to look the difference between high and low source credibility, that is endorser and corporate credibility, that influence purchase intention in airlines advertisement. Therefore, based on existing literature, this study tested the following hypotheses:

H1: The group that is exposed advertisement with high endorser credibility has greater purchase intention than group with low endorser credibility.

$\mathrm{H} 2$ : The group that is exposed advertisement with high corporate credibility has greater purchase 
intention than group with low corporate credibility.

H3: There is an interaction between endorser and corporate credibility that influence consumer purchase intention.

\section{Methods}

Sample. Sample of this study was 520 men and women aged 21-34 years old, and lived at the greater Jakarta area during the collection of the data. The recruitment of the sample would be done by spreading the research link in the social media such as LINE, Facebook, Instagram, Whatsapp, etc. The age group was chosen because individuals in the aforementioned age bracket are more likely to engage with online promotional messages (Nielsen Company, 2015).

Research Design. The design of this study was 2 (high vs low endorser credibility) x 2 (high vs low corporate credibility) experimental design. The 520 participants were randomly assigned into four groups. The first group received a promotional message from high-credibility corporation and endorser, the second group received promotional message from highcredibility corporate and low endorser credibility, the third group received promotional message from low-credibility corporate and highcredibility endorser, and the last group was exposed low corporate and endorser credibility.

Instrument and Measurement. Endorser credibility was measured using a scale developed by Ohanian (1990). This scale consisted of six items with seven point scale ( $1=$ strongly disagree to $6=$ strongly agree). Some example of the items were "attractive - unattractive" and "classy not classy'. Prior to the experiment, the researchers distributed the simple survey to 30 individuals to determine the celebrity that will be perceived as having high or low credibility, respectively, for airline advertisement. Based on the survey, the researcher got Ali Syakieb as the high credibility endorser and Syaiful Jamil as the low credibility endorser.

As mentioned, in the experiment, participants were randomly assigned into four groups. The layout and script of the advertisement were made exactly the same in each manipulation to eliminate the possibility of confound. The script consisted of short quote of the endorser about the airlines. Manipulation check was conducted by asking the participants to rate the endorser credibility after they received the advertisement.

The second independent variable in this study was corporate credibility. In this study, corporate credibility was measured using the Corporate Credibility Scale developed by Newell and Goldsmith (2001). ." This scale consisted of eight items, four items measure the company honesty and four items measure company expertise. Participants responded to five-item Likert Scale ( $1=$ strongly disagree; $5=$ strongly agree). The example of the items were "Komodo Airlines doesn't have much experience in aviation" and "Komodo Airlines makes truthful claimsThe manipulation of corporate credibility was based on fictitious description of airline company to avoid previous knowledge about the airline. Descriptions about airline credibility were based on baseline results about airlines in Indonesia. The exposure of the description was to influence participant perception about credibility of airlines. One company showed positive image, while another company showed the description in negative way. The manipulation was adapted from procedure by Goldberg and Hartwick (1990). The descriptions of the airline were showed equally in length of sentence and visual information. Manipulation check was conducted by asking participants to assess the credibility of the company.

The dependent variable in this study was purchase intention, measured using a scale developed by Junghwa (2013). In this scale, participants were asked to fill five items about how much possibility to buy the airlines ticket. The example of the items are "The probability to buy the ticket of Komodo Arlines" and "If I would buy an airline ticket, I would consider to buy the tickets of Komodo Airlines". Participants responded in seven-point scale $(1=$ very unlikely; 7 = very likely).

Procedure. Four advertisements with different treatment were prepared and distributed online. When they opened the link, participants would randomly get one of the advertisements. The first page contained general instruction. Participants were asked to respond to all questions. The second page contained informed consent. There was description about the airlines in the next page, either in negative or positive way. There 
was also picture of the airlines with the endorser, either Ali Syakieb or Syaiful Jamil. Participants were asked to read the description and look at the advertisement carefully.

In the subsequent page, participants were asked to answer the questions about the intention to purchase airline ticket, followed by the page containing manipulation checks about endorser and corporate credibility. The effectiveness manipulation of endorser was measured by endorser credibility instrument by Ohanian (1990), while corporate credibility was measured using Corporate Credibility Scale by Newell and Goldsmith (2001). The next page contained participants demographic information, the frequency of using airlines in the past year, the main criteria in choosing airlines. In this page participants were also asked to guess the objective of this study in order to minimize the likelihood of the having the responses resulted from Hawthorne effect. The next page contained question to recheck which celebrity and article that they had seen. Participants received debriefing before leaving the online experiment.

\section{Results}

Manipulation Checks. The results indicated that both manipulations endorser and corporate credibility were successful. The manipulation of endorser attractiveness was significant $t(559)=$ $11,654, \mathrm{p}<0,05)$, indicating participant felt that high-credibility endorser $(M=9,02)$ was more attractive than low-credibility endorser $(M=$ 5,92). The manipulation of endorser trustworthiness was also significant $t(559)=$ $11,528, p<0,05)$. High credibility endorser was perceived more trustworthy $(\mathrm{M}=8,53)$ than the low-credibility endorser $(M=5,61)$. The last, manipulation of endorser expertise was also successful $t(559)=10,4, p<0,05)$, indicating that high credibility endorser was perceived more expert $(M=8,86)$ than low credibility endorser $(\mathrm{M}=6,27)$.

The manipulation of corporate expertise and honesty were successful. The ANOVA results indicated that manipulations of corporate honesty was significant $t(559)=10,439, p<0,05$. Participant felt that high credibility corporate was perceived more honest $(\mathrm{M}=13,46)$ than low credibility corporate $(\mathrm{M}=9,69)$. The manipulation of company expertise was also significant $t(559)=13,191, p<0,05$, indicating high corporate credibility was perceived more expert $(\mathrm{M}=12,83)$ than low corporate credibility $(\mathrm{M}=10,03)$.

Purchase Intention. However, there was a significant main effect for endorser credibility, $F(1,559)=25,483 ; p<0,05$. This indicated that high-credibility endorser had more positive effect on purchase intention $(\mathrm{M}=18,369)$ than lowcredibility endorser $(M=14,813)$, thus H1 was supported. There was also significant main effect for corporate credibility, $F(1,559)=34,37$; $\mathrm{p}<0,05)$. Company with high credibility also generated more positive effect on purchase intention $(M=18,656)$ than it low-credibility counterpart $(M=14,53$. Therefore, $\mathrm{H} 2$ was supported. However, no significant interaction effect of endorser and corporate credibility on purchase intention was found $(p=, 053)$, therefore H3 was not supported.

Table 1.

One Way ANOVA Result

\begin{tabular}{lllll} 
Variabel & $\mathbf{D} \boldsymbol{f}$ & $\mathbf{F}$ & $\mathbf{P}$ & $\boldsymbol{\eta}^{2}$ \\
\hline $\begin{array}{l}\text { Endorser } \\
\text { Credibility }\end{array}$ & 1 & 25,48 & 0,00 & 0,04 \\
$\begin{array}{l}\text { Corporate } \\
\text { Credibility }\end{array}$ & 1 & 34,37 & 0,00 & 0,06 \\
$\begin{array}{l}\text { Interaction } \\
\text { between }\end{array}$ & 1 & 3,76 & 0,053 & 0,01 \\
$\begin{array}{l}\text { Endorser and } \\
\text { Corporate } \\
\text { Credibility }\end{array}$ & & & & \\
Error & 559 & & & \\
& & & & \\
Total & 563 & & & \\
\hline
\end{tabular}

\section{Discussion and Conclusion}

Discussion. The result of this study indicated that endorser credibility has significant effect on purchase intention. It was not consistent the result Lafferty and Golsmith's (1999) study that stated endorser credibility doesn't have significance effect on purchase intention. The result of this study supported two studies by Goldsmith et al. (2000) that stated high credibility endorser will lead higher purchase, compared with low credibility endorser. In this study, researcher presumed that high credibility endorser that was 
used in the ad was really considered an expert and could be trusted by the participant to advertise airlines. Furthermore, the high-credibility endorser in this ad also has profession as a pilot. A pilot would be considered more expert compared to low credibility endorser, such as singer.

This study indicated the influence corporate credibility on consumers' purchase intention, which corroborated the results of by Lafferty and Goldsmith's study (1999). This study was also consistent with Newell (1993) that stated credible company would be positively associated with purchase intention. Besides that, the result of this study supported Fombrun (1996) that stated perception about company played important role in development of purchase intention. The researcher assumed that even though the airlines name that was used in this study was hypothetical, positive description about company reputation would give more trust to the consumer and could increase consumers' desire to purchase airlines ticket.

The result of this study indicated that endorser and corporate credibility indepently influence purchase intention and did not interact. It was consistent with the study by Goldsmith (2000) and Lafferty and Goldsmith (1999). A plausible explanation for the absence of the interaction is because in the description of corporate credibility appeared in the same page with the picture of endorser. It could make the pariticipants just focused on one of two variables that were being measured. When the participants read the negative company description, they might not focus on the picture of endorser. Similarly, when the participants saw the picture of high-credibility endorser, they would get attracted to the advertisement, regardless of the company description.

Limitation. This study has some limitations. First, the findings of this study are limited to the product, media, and endorsers that were tested. Future research should use other product or celeb to explain generalizability of this study. Second, sample that was used in this study was heterogeneous. The future research can use homogeneous sample, such as use only male sample or only female sample, because effect on each gender will be different. Third, the sample in this study was limited to the young adults, aged 21-34 years old. Future research can include younger age group, such as teenager, or even older age group.

Conclusions. The result of this study showed that endorser and corporate credibility has significant effect on purchase intention. Specifically, endorsers with high credibility are more likely to generate intention to purchase among consumers. Similarly, consumers are more likely to express stronger intention to purchase when the advertisement comes from company with high credibility.

\section{Reference}

Fatima, S. \& Lodhi, S. (2015). Impact of advertisement on buying behaviours of the consumers: study of cosmetic industry in Karachi City. International Journal of Management Sciences and Business Research, 4(10), 125-37.

Fombrun, C. (1996). Reputation. John Willey \& Sons, Ltd.

Gangeshwer, D. K. (2013). E-commerce or internet marketing: A business review from Indian context. International Journal of $u$-and $e$ Service, Science and Technology, 6(6), 187194.

Goldsmith, R. E., Lafferty, B. A., \& Newell, S. J. (2000). The influence of corporate credibility on consumer attitudes and purchase intent. Corporate Reputation Review, 3(4), 304-318.

Goldberg, M. E., \& Hartwick, J. (1990). The effects of advertiser reputation and extremity of advertising claim on advertising effectiveness. Journal of Consumer Research, 17(2), 172-179.

Kim, S., Wang, K., Jhu, W., \& Gao, Y. (2015). The best match-up of airline advertising endorsement and flight safety message. International Journal of Contemporary Hospitality Management, 28(11), 2533-2552.

Lafferty, B. A. \& Goldsmith, R. E. (1999). Corporate credibility's role in consumers' attitudes and purchase intentions when a high versus a low credibility endorser is used in the ad. Journal of business research, 44(2), 109-116.

McCormick, K. (2016). Celebrity endorsements: Influence of a product-endorser match on Millenials attitudes and purchase intentions. Journal of retailing and consumer services, 32, $39-45$. 
Mirabi, V., Akbariyeh, H., \& Tahmasebifard, H. (2015). A Study Of Factors Affecting on Customers Purchase Intention. Journal of Multidisciplinary Engineering Science and Technology (JMEST), 2(1), 267-273.

Ohanian, R. (1990), Construction and Validation of A Scale to Measure Celebrity Endorser's Perceived Expertise, Trustworthiness, and Attractiveness. Journal of Advertising, 19(3), 39- 52.

Ohanian, R. (1991), The Impact of Celebrity Spokespersons' Perceived Image on Customers' Intention to Purchase. Journal of Advertising Research, 31(1), 46-54.

Park, J. W., Robertson, R., \& Wu, C. L. (2004). The effect of airline service quality on passengers' behavioural intentions: a Korean case study. Journal of Air Transport Management, 10(6), 435-439.

Raju, K. V., \& Kumar, D. P. (2013). The role of advertising in consumer decision making. Journal of Business and Management, 14(4), $37-45$.

Samat, M. F., Ramlee, N. A., Abu Bakar, H. Annual, N., \& Rasid, M. F (2016). Endorser credibility and its influence on the purchase intention of social networking sites consumer: a mediating role of attitude towards sns advertising. International Journal of Management and Applied Science, 2(12), 50-56.

Tai, H. T., \& Chang, S. S. (2005). The causal model of internet advertising effectiveness. Asia Pacific Management Review, 10(1), 78-92.

Zaichkowsky, J.L. (1985). Measuring the involvement construct. Journal of Consumer Research, 12 (3), 341-352.

Zipporah, M. M., \& Mberia, H. K. (2014). The effects of celebrity endorsement in advertisements. International Journal of Academic Research in Economics and Management Sciences, 3(5), 178. 